DOI: 10.22630/EIOGZ.2014.107.29

Zeszyty Naukowe Szkoły Głównej Gospodarstwa Wiejskiego

Ekonomika i Organizacja Gospodarki Żywnościowej nr 107, 2014: 103-114

Barbara Roszkowska-Mądra

Katedra Nauk o Przedsiębiorstwie

Uniwersytet w Białymstoku

\title{
Zmiany w rolnictwie województwa podlaskiego po integracji z Unią Europejską
}

\section{Wstęp}

Przystapienie Polski do struktur unijnych przyczyniło się do zmian warunków gospodarowania w rolnictwie, które jest wciąż ważną gałęzią gospodarki narodowej. Wynika to przede wszystkim z objęcia polskiego rolnictwa Wspólną Polityką Rolną. Jednakże jego rozwój w poszczególnych regionach Polski jest zróżnicowany [Kulikowski 2003, s. 179-185]. Ma to swoje przyczyny głównie w przestrzennej różnorodności posiadanego potencjału rozwojowego oraz efektach oddziaływania sił zewnętrznych na różnych szczeblach zarządzania publicznego, zarówno rządowego, jak i samorządowego. Zatem pojawia się potrzeba oceny zmian w rolnictwie polskim na poziomie regionów po akcesji do UE. Wyniki takich badań mogą być wykorzystane do elastycznego (zdywersyfikowanego) wdrażania tych form zarządzania publicznego, które dotyczą interwencjonizmu państwowego i samorządowego, polegającego na wytyczaniu i programowaniu głównych kierunków rozwoju rolnictwa w regionie, zgodnie $\mathrm{z}$ paradygmatem zrównoważonego rozwoju rolnictwa i obszarów wiejskich, a także na stosowaniu odpowiednich instrumentów wspierających te kierunki rozwoju.

Województwo podlaskie to obszar, którego dominującą funkcją gospodarczą jest rolnictwo. Obszar ten jest silnie zróżnicowany pod względem przyrodniczym, społeczno-ekonomicznym, historycznym, etnicznym i kulturowym. Jego specyfiką są mniej korzystne warunki przyrodnicze do prowadzenia produkcji rolniczej niż w wielu innych regionach kraju, a także ogólnie duży, choć nierównomiernie rozłożony przestrzennie udział obszarów przyrodniczo cennych i chronionych oraz o wybitnych walorach turystyczno-rekreacyjnych. Prawie 
cały obszar wiejski województwa został w 2004 roku zakwalifikowany do obszarów o mniej korzystnych warunkach do prowadzenia działalności rolniczej, określanych obszarami o niekorzystnych warunkach gospodarowania w rolnictwie (w skrócie ONW). Udział nizinnych ONW w województwie podlaskim jest największy wśród województw w Polsce. To predestynuje rozważany region do rozwoju agroturystyki, dając możliwości uzyskiwania dodatkowego źródła dochodów ludności wiejskiej związanej z prowadzeniem rolniczej działalności gospodarczej. Dochody tej grupy ludności są przeważnie niskie, zwłaszcza na Podlasiu, będące między innymi pochodną niskiej wydajności pracy w tym sektorze gospodarki. Mimo mniej korzystnych warunków do gospodarowania $\mathrm{w}$ rolnictwie $\mathrm{w}$ województwie podlaskim, ten dział gospodarki w regionie wytwarza aż 6,3\% krajowej produkcji towarowej rolnictwa, co plasuje go na szóstym miejscu w kraju i na pierwszym miejscu pod względem produkcji mleka na 1 ha użytków rolnych [Rocznik Statystyczny Województw 2011]. Przedstawiona krótka charakterystyka wskazuje, że województwo podlaskie posiada ogromny potencjał do rozwoju rolnictwa, który nie jest jeszcze dobrze wykorzystany. Zatem uzasadnione jest dokonanie analizy zmian w rolnictwie rozpatrywanego województwa po przystąpieniu Polski do struktur unijnych pod względem podstawowych czynników produkcji rolniczej, tj. ziemi, pracy i kapitału, określających możliwości wytwórcze gospodarstw rolniczych w tym województwie, a także wyników produkcyjnych. Na tej podstawie można dokonać próby określenia kierunków rozwoju rolnictwa podlaskiego. Umożliwi to podejmowanie racjonalnych działań na rzecz aktywizacji obszarów wiejskich. Wydaje się, że działania te powinny zmierzać głównie do utrzymania rolniczego użytkowania ziemi i żywotności obszarów wiejskich oraz utrzymania ich naturalnego krajobrazu, kultury i tradycji, która jest tak bardzo istotna dla każdego człowieka.

\section{Cele i metody}

Celem podjętych badań była ocena zmian, jakie dokonały się w rolnictwie województwa podlaskiego po przystąpieniu Polski do Unii Europejskiej, tj. w latach 2002-2010, w porównaniu do zmian, jakie w tym okresie wystapiły w kraju. Podstawowy materiał empiryczny stanowiły wyniki powszechnego spisu rolnego PSR 2002 i PSR 2010 oraz literatura przedmiotu. W badaniach skoncentrowano się na analizie zmian, które zaszły pod względem podstawowych czynników produkcji rolniczej, tj. ziemi, pracy i kapitału, określających możliwości wytwórcze gospodarstw rolniczych w województwie podlaskim, a także w ich wynikach produkcyjnych. To pozwoliło podjąć próbę oceny implementacji funduszy unijnych do rolnictwa i określić możliwe kierunki jego rozwoju w badanym województwie. 
W pracy zastosowano takie metody badawcze, jak studia literatury przedmiotu, analizę opisową, analizę porównawczą, analizę przyczynowo-skutkową, metody statystyczne (wskaźniki dynamiki, struktury), wnioskowanie indukcyjne.

\section{Wyniki badań i dyskusja}

\section{Zmiany w zasobach czynników wytwórczych i wynikach produkcji rolniczej $w$ regionie}

Zasoby ziemi wykorzystywane na cele rolnicze, zarówno w Polsce, jak i w analizowanym województwie, ulegają sukcesywnemu zmniejszaniu. Użytki rolne w ogólnej powierzchni województwa stanowią 56,8\% (szóste miejsce w kraju), w stosunku do 2002 roku ich udział zmniejszył się o 3,1 p.p., przeważają na nich gleby słabe o niskiej wartości produkcyjnej. Wskaźnik waloryzacji rolniczej przestrzeni produkcyjnej (WWRPP), opracowany przez IUNiG w Puławach, który uwzględnia w sposób syntetyczny jakość i przydatność rolniczą składowych środowiska (gleba, agroklimat, rzeźba terenu, stosunki wodne), wynosi zaledwie 55 punktów i jest o 11 punktów niższy od występującego średnio w kraju. Udział gleb o bardzo małych możliwościach produkcyjnych wynosi prawie 45\%. Część z nich w latach 2002-2010 uległa zalesieniu (4,8 tys. najsłabszych gleb). Działania te mogły być realizowane ze środków oferowanych polskim rolnikom w ramach Planu i Programu Obszarów Wiejskich w latach 2004-2006 i 2007-2013. To przyczyniło się do tworzenia takich warunków gospodarowania, które zapewniałyby lepsze możliwości realizacji idei zrównoważonego rozwoju rolnictwa i obszarów wiejskich na płaszczyźnie środowiskowej.

Województwo podlaskie charakteryzuje niższy udział gruntów ornych $(56,7 \%)$ w strukturze użytków rolnych w stosunku do przeciętnego w kraju, który wynosi $67,2 \%$. Rozpatrywany region charakteryzuje się natomiast 37,9-procentowym udziałem trwałych użytków zielonych w strukturze użytków rolnych, który jest największy w kraju oraz dwukrotnie wyższy od średniej krajowej. Predestynuje to województwo podlaskie do rozwoju produkcji zwierzęcej, zwłaszcza chowu bydła.

Potencjał produkcyjny rolnictwa w 2010 roku (tab. 1) tworzyło 104 tys. gospodarstw rolnych, co stanowi 87\% stanu z 2002 roku. Podobna tendencja spadkowa w tym zakresie wystapiła również w innych regionach kraju. W Polsce ubyło 655,6 tys., tj. 22,4\% gospodarstw. Spośród 104 tys. gospodarstw rolnych w województwie, 92,3 tys. prowadziło działalność rolniczą, a ich przeciętna powierzchnia wynosiła 11,4 ha i była większa o 4 ha UR niż średnio w kraju. 


\section{6}

\section{Tabela 1}

Liczba, powierzchnia UR i średnia powierzchnia gospodarstw rolnych ogółem i w odniesieniu do gospodarstwach prowadzących działalność rolniczą w województwie podlaskim w latach 2002 i 2010

\begin{tabular}{|l|r|r|r|}
\hline \multirow{2}{*}{ Wyszczególnienie } & 2002 & 2010 & $2002=100$ \\
\cline { 2 - 4 } & \multicolumn{3}{|c|}{ Ogółem } \\
\hline Liczba gospodarstw rolnych [tys.] & 120,10 & 104,00 & 86,60 \\
\hline Powierzchnia użytków rolnych [tys. ha] & 1149,80 & 1059,80 & 92,20 \\
\hline Średnia powierzchnia gospodarstwa [ha] & 9,58 & 10,19 & 106,40 \\
\hline \multicolumn{3}{|c|}{ w tym gospodarstw prowadzących działalność rolnicza } \\
\hline Liczba gospodarstw rolnych [tys.] & 95,90 & 92,30 & 96,20 \\
\hline Powierzchnia użytków rolnych [tys. ha] & 1083,30 & 1051,00 & 97,00 \\
\hline Średnia powierzchnia gospodarstwa [ha] & 11,29 & 11,38 & 100,80 \\
\hline
\end{tabular}

Źródło: Analiza kluczowych sektorów województwa podlaskiego - sektor rolnictwa, WUP, Białystok 2012, s. 70.

Niepokojącym zjawiskiem jest duży i wzrastający udział gospodarstw rolnych prowadzących wyłącznie produkcję roślinna. W 2002 roku wynosił on $22,2 \%$, a w 2010 udział ten wzrósł do 37,5\%. Tendencja ta może być pierwszą ważną oznaką sukcesywnego odchodzenia od rolniczego gospodarowania i coraz mniejszego rolniczego wykorzystania zasobów przyrodniczych, społecznych i ekonomicznych [Roszkowska-Mądra 2010, s. 277]. Może ona wskazywać także na zawężającą się dywersyfikację produkcji rolniczej, polegającą na pogłębianiu się specjalizacji gospodarstw rolnych oraz ich coraz ściślejszej kooperacji (niektórzy rolnicy produkują głównie pasze, które sprzedają lokalnym producentom zwierząt, wyspecjalizowanym w tym zakresie).

Struktura obszarowa gospodarstw prowadzących działalność rolniczą na tle rolnictwa w kraju w analizowanym okresie wyglądała korzystnie. Charakteryzował ją blisko dwukrotnie mniejszy udział gospodarstw w przedziale 1-5 ha UR w porównaniu do średniej krajowej i nieco większy udział gospodarstw o powierzchni 5-10 ha (tab. 2). Udział gospodarstw powyżej 10 ha UR wynosił $44,3 \%$ i był blisko dwukrotnie wyższy niż średnia krajowa, co świadczy o dość dużych możliwościach rozwojowych tego sektora w regionie. Analiza danych ARiMR pozwala stwierdzić, że program rent strukturalnych w tym regionie oddziaływał pozytywnie na przemiany struktury obszarowej gospodarstw rolnych i przyczynił się do jej korzystnych zmian. Przekazane gospodarstwa za renty strukturalne w latach 2004-2006 stanowiły 20\% zlikwidowanych gospodarstw rolnych ogółem [Kozłowska-Burdziak 2012].

Czynnik pracy nie jest jednorodny, dlatego też należy go rozpatrywać w dwóch wymiarach. Pierwszy wymiar ma charakter ilościowy, drugi zaś jako- 
Tabela 2

Zmiany w strukturze obszarowej gospodarstw rolnych powyżej 1 ha UR w Polsce i województwie podlaskim w latach 2002-2010

\begin{tabular}{|c|c|c|c|c|c|c|c|}
\hline \multirow{2}{*}{\multicolumn{2}{|c|}{ Wyszczególnienie }} & \multicolumn{6}{|c|}{ Udział gospodarstw według grup obszarowych [ha UR] } \\
\hline & & $1-2$ & $2-5$ & $5-10$ & $10-15$ & $15-30$ & $>30$ \\
\hline \multirow[t]{2}{*}{ Polska } & \multirow{2}{*}{$\begin{array}{l}2002 \\
2010\end{array}$} & 26,5 & 32,2 & 21,8 & 9,3 & 7,6 & 2,6 \\
\hline & & 21,9 & 33,3 & 22,6 & 9,7 & 8,5 & 4,0 \\
\hline \multirow{2}{*}{$\begin{array}{l}\text { Województwo } \\
\text { podlaskie }\end{array}$} & \multirow{2}{*}{$\begin{array}{l}2002 \\
2010\end{array}$} & 13,3 & 18,6 & 24,6 & 19,1 & 20,0 & 4,4 \\
\hline & & 9,4 & 20,7 & 25,6 & 18,4 & 19,9 & 6,0 \\
\hline
\end{tabular}

Źródło: Analiza kluczowych sektorów województwa podlaskiego - sektor rolnictwa, WUP, Białystok 2012, s. 111.

ściowy. W 2010 roku udział zatrudnionych w rolnictwie w strukturze gospodarki kraju wynosił 12,9\% ogółu zatrudnionych, dla porównania w województwie podlaskim był on niemalże dwukrotnie wyższy i wynosił $31,2 \%$, co wskazuje na kluczową rolę tego sektora $\mathrm{w}$ gospodarce regionu. Na obszarach wiejskich województwa podlaskiego największą grupę stanowiły osoby będące w wieku poprodukcyjnym (46\%), najmniejszą zaś w wieku produkcyjnym $(37,1 \%)$, co nie jest korzystną okolicznościa, aczkolwiek te niekorzystne proporcje dotyczyły również pozostałych regionów kraju. Specyficzną cechą tego regionu, w odniesieniu do reszty kraju, jest większy spadek ludności w wieku przedprodukcyjnym, co może wpływać na kurczenie się zasobów pracy w rolnictwie. Pozytywnym zjawiskiem jest natomiast wzrost poziomu wykształcenia osób pracujących w rolnictwie, zarówno średnio w kraju, jak i w analizowanym regionie. Wykształceniem wyższym w 2010 roku legitymowało się w województwie podlaskim 11,6\% kierowników gospodarstw rolnych (średnia w kraju 10,3\%), co w porównaniu do 2002 roku stanowiło wzrost o 7,8 p.p. [Ludność i gospodarstwa... 2012]. Korzystne zjawiska odnoszą się również do wzrostu przygotowania zawodowego kierowników gospodarstw rolniczych. W 2010 roku blisko 48\% kierujących gospodarstwami rolnymi posiadało wykształcenie rolnicze, co stanowiło niemalże dwukrotnie więcej niż w 2002 roku. To świadczy o pozytywnym wpływie finansowania transferu wiedzy do tej grupy zawodowej, umożliwiając w ten sposób wzmocnienie pozycji konkurencyjnej polskich gospodarstw rolniczych na rynku unijnym. Wzrost poziomu wykształcenia zaowocował zróżnicowaniem systemów gospodarowania w rolnictwie, a mianowicie zwiększyła się liczba gospodarstw produkujących metodami ekologicznymi, których kierownicy z racji licznych wymogów tej produkcji muszą posiadać duże zasoby specjalistycznej wiedzy. W 2010 roku w województwie podlaskim funkcjonowało 2033 gospodarstw ekologicznych (ogółem w kraju było ich 25 944), dla porównania w 2003 roku takich gospodarstw było w województwie zaledwie 122 (w tym 
7 gospodarstw w trakcie przestawiania na produkcję ekologiczna). W 2010 roku dla 2020 gospodarstw ekologicznych, tj. 99\% tego typu gospodarstw funkcjonujących w województwie podlaskim, ARiMR wypłaciła kwotę 24116667 zł z tytułu realizacji pakietu Rolnictwo ekologiczne w ramach programów rolnośrodowiskowych [Analiza kierunków... 2011, s. 91].

Nakłady inwestycyjne w rolnictwie województwa podlaskiego w 2010 roku wynosiły 259,7 zł na 1 ha UR i były w stosunku do średniej krajowej większe o 20 zł na 1 ha UR. Analiza danych zawartych w powszechnych spisach rolnych z 2002 i 2010 roku wskazuje, że w analizowanym okresie w województwie nastapił wzrost liczby ciągników rolniczych o blisko $18 \%$ oraz o $27 \%$ kombajnów zbożowych, co ma niewątpliwie pozytywny wpływ na możliwość terminowego wykonywania prac polowych oraz $\mathrm{w}$ większym stopniu przestrzeganie reżimu technologicznego. W województwie podlaskim w 2010 roku odnotowano najwyższy w kraju udział gospodarstw z ciaggnikami w ogólnej liczbie gospodarstw prowadzących działalność rolniczą [Charakterystyka gospodarstw... 2012, s. 75]. Zmiany te umożliwiło wsparcie finansowe realizowane w ramach Działania 1.1 „Inwestycje w gospodarstwach rolnych” Sektorowego Programu Operacyjnego „Restrukturyzacja i modernizacja sektora żywnościowego oraz obszarów wiejskich 2004-2006", które pozwoliło dofinansować inwestycje w gospodarstwach rolnych na kwotę $206 \mathrm{mln}$ zł oraz Działania 121 „Modernizacja gospodarstw rolnych", realizowanego w ramach PROW 2007-2013, które przyczyniło się znacząco do wsparcia poziomu mechanizacji gospodarstw rolnych. Przeciętny poziom dofinansowania jednego projektu $\mathrm{w}$ ramach tego działania $\mathrm{w}$ województwie podlaskim był o 43,36 tys. zł większy niż średnio w kraju i wynosił 146,35 tys. zł [Analiza kluczowych... 2011, s. 22]. W analizowanym okresie odnotowano wzrost zużycia nawozów mineralnych, zarówno w skali całego kraju, jak i w analizowanym regionie, aczkolwiek jego zużycie w województwie podlaskim w roku gospodarczym 2010/2011wynosiło 94,9 kg NPK/1ha UR i było o 25\% niższe niż średnio w kraju. Fakt ten predestynuje województwo do prowadzenia produkcji metodami ekologicznymi, która może stanowić potencjalnie atrakcyjną ofertę eksportową podlaskiego rolnictwa. Jednak niepokojącym zjawiskiem występującym nie tylko w badanym województwie, ale również w skali całego kraju, jest niedocenianie przez rolników nawożenia wapniowego, które odgrywa doniosłe znaczenie w plonowaniu roślin. W województwie podlaskim stosowano je w niewielkiej ilości - 14,5 kg Ca/1 ha, co stanowiło zaledwie 39\% dawki w kraju [Środki produkcji... 2011]. Efektem tego jest utrzymywanie się dużego udziału w strukturze użytków rolnych gleb o odczynie kwaśnym i bardzo kwaśnym.

Wzrost jakości kapitału ludzkiego w rolniczych gospodarstwach domowych, wspierany w ramach Wspólnej Polityki Rolnej i polityki spójności, przekłada 
się na wzrost ich przedsiębiorczych zachowań, które uwidaczniają się w przyspieszeniu procesu specjalizacji gospodarstw, poszukiwaniu nowych dziedzin działalności, tworzeniu postępu organizacyjnego i technicznego. Ich realizacja na poziomie gospodarstwa rolnego może uwidaczniać się $\mathrm{w}$ wielozawodowości rolników oraz w ekonomicznej dywersyfikacji gospodarstwa. Jest to zjawisko, które w krajach Unii Europejskiej dotyczy około 1/3 rolniczych gospodarstw domowych. Zdecydowanie w większym stopniu odnosi się ono do gospodarstw o niskiej sile ekonomicznej (poniżej 1 ESU) niż do gospodarstw dużych (powyżej 16 ESU) [Wilkin 2010]. W województwie podlaskim gospodarstw o niskiej (do 4 ESU) i wysokiej sile ekonomicznej (ponad 25 ESU) w 2010 roku odnotowano 44,0\% (średnio w kraju 61,2\%) i 16\% (przy średniej krajowej 7,9\%). W stosunku do średniej krajowej jest to wynik korzystny. Konsekwencją tego zjawiska był dominujący ( $w$ porównaniu do pozostałych województw) udział gospodarstw utrzymujących się przede wszystkim z rolnictwa $(46,7 \%)$ w ogólnej strukturze gospodarstw i najwyższy odsetek $(79,3 \%)$ gospodarstw przeznaczających ponad 50\% swojej produkcji na sprzedaż. Gospodarstwa produkujące głównie na cele samozaopatrzenia stanowiły 20,7\%. Dane zawarte w tabeli 3 wskazują, że w analizowanym okresie nastąił wzrost zainteresowania rolników prowadzeniem działalności pozarolniczej. Tendencja ta dotyczyła nie tylko badanego województwa, ale była ogólnie powszechna w kraju. Rolnicy w badanym regionie najczęściej podejmowali się prowadzenia działalności agroturystycznej i przetwórstwa. Jednak działalność rolnicza dla nieomal połowy rolniczych gospodarstw domowych w regionie stanowiła w dalszym ciągu dominujące źródło zarobkowania. Na rozwój działalności pozarolniczej wpływ wywarły działania SPO „Różnicowanie działalności rolniczej i zbliżonej do rolnictwa w celu zapewnienia różnorodności działań lub alternatywnych źródeł dochodów" oraz Programu Rozwoju Obszarów Wiejskich na lata 2007-2013 „Różnicowanie w kierunku działalności nierolniczej”. Udział województwa podlaskiego w puli środków przeznaczonych na realizację działania „Różnicowanie w kierunku działalności nierolniczej” wyniósł 5,9\%, co uplasowało go na 8. miejscu w kraju. W latach 2008-2011 zawarto 1540 umów na łączną kwotę 88270153 zł, co stanowiło 7,8\% udziału zrealizowanych płatności w kraju. W strukturze rodzajów powstałych działalności dominowały usługi dla gospodarstw rolnych lub leśnictwo $(55,4 \%)$ i usługi turystyczne oraz związane ze sportem, rekreacją i wypoczynkiem [www.arimr.gov.pl].

W strukturze towarowej produkcji rolniczej województwa podlaskiego dominuje produkcja zwierzęca, która według danych PSR 2010 stanowiła blisko $90 \%$, podczas gdy średnio w kraju $62,3 \%$. W towarowej produkcji zwierzęcej dominuje produkcja mleka (blisko 50-procentowy udział). Jest to konsekwencją wysokiej liczby bydła (w tym krów) w regionie, która w 2010 roku wynosiła 
879,0 tys. sztuk (w tym krów 474,4 tys. sztuk). W stosunku do liczebności stada z 2002 roku pogłowie bydła zwiększyło się o blisko 28\% (w tym krów o 21,7\%), przy jednoczesnym zmniejszeniu liczby gospodarstw rolnych zajmujących się chowem bydła z 61 do ok. 44 tys. (o 27,5\%), co spowodowało dalszy wzrost specjalizacji w tym regionie. Obsada bydła w województwie podlaskim w 2010 roku wynosiła 82,9 szt. na 100 ha UR, co dawało 2. miejsce w kraju (średnio w kraju obsada bydła wynosiła 37,0 szt. na 100 ha UR) [Raport 2010].

\section{Tabela 3}

Gospodarstwa rolne według przeważającego dochodu gospodarstw domowych w 2002 i 2010 roku w województwie podlaskim na tle kraju

\begin{tabular}{|c|c|c|c|c|c|c|c|c|}
\hline \multirow[b]{2}{*}{$\begin{array}{l}\text { Wyszcze- } \\
\text { gólnienie }\end{array}$} & \multicolumn{7}{|c|}{$\begin{array}{l}\text { Gospodarstwa domowe, w których ponad } 50 \% \text { dochodów ogółem } \\
\text { stanowiły dochody z: }\end{array}$} & \multirow[b]{2}{*}{$\begin{array}{c}\text { Gospo- } \\
\text { darstwa } \\
\text { pozo- } \\
\text { stałe }\end{array}$} \\
\hline & $\begin{array}{c}\text { działal- } \\
\text { ności } \\
\text { rolniczej }\end{array}$ & \begin{tabular}{|c|} 
działal- \\
ności \\
rolniczej \\
i pracy \\
najem- \\
nej \\
\end{tabular} & $\begin{array}{l}\text { pracy } \\
\text { najem- } \\
\text { nej }\end{array}$ & $\begin{array}{c}\text { pracy } \\
\text { najem- } \\
\text { nej } \\
\text { i dzia- } \\
\text { łalności } \\
\text { rolniczej } \\
\end{array}$ & $\begin{array}{c}\text { działal- } \\
\text { ności } \\
\text { pozarol- } \\
\text { niczej }\end{array}$ & $\begin{array}{l}\text { emery- } \\
\text { tury } \\
\text { i renty }\end{array}$ & $\begin{array}{l}\text { nieza- } \\
\text { robko- } \\
\text { wych } \\
\text { źródeł } \\
\text { utrzy- } \\
\text { mania }\end{array}$ & \\
\hline $\begin{array}{l}\text { Polska } \\
2002\end{array}$ & 20,8 & 0,9 & 27,1 & 2,7 & 5,8 & 30,9 & 5,2 & 6,6 \\
\hline $\begin{array}{l}\text { Polska } \\
2010\end{array}$ & 27,6 & 0,7 & 31,1 & 2,0 & 9,5 & 19,7 & 3,1 & 6,3 \\
\hline $\begin{array}{l}\text { Wojewódz- } \\
\text { two podla- } \\
\text { skie } 2002\end{array}$ & 38,2 & 1,2 & 19,2 & 1,8 & 5,0 & 25,5 & 3,6 & 5,5 \\
\hline $\begin{array}{l}\text { Wojewódz- } \\
\text { two podla- } \\
\text { skie } 2010\end{array}$ & 46,7 & 0,9 & 23,1 & 1,2 & 8,9 & 11,3 & 1,9 & 6,0 \\
\hline
\end{tabular}

Źródło: Charakterystyka gospodarstw rolnych, Powszechny Spis Rolny 2010, GUS, Warszawa 2012.

Produkcja roślinna w strukturze towarowej produkcji rolniczej w 2009 roku stanowiła 11,2\% [Rocznik Branżowy 2011]. Wyniki PSR 2010 wykazały, że od poprzedniego spisu z 2002 roku zmniejszyła się ogólna powierzchnia zasiewów w województwie. Zmianie uległa również jej struktura. W stosunku do roku 2002 odnotowano spadek udziału zbóż i niemal trzykrotny spadek produkcji ziemniaków w ogólnej powierzchni zasiewów. Wzrosła natomiast ponad dwukrotnie w stosunku do 2002 roku powierzchnia upraw roślin pastewnych (łącznie z kukurydzą na kiszonkę), co jest związane ze wzrostem zapotrzebowania na pasze $\mathrm{z}$ powodu wzrastającego pogłowia bydła $\mathrm{w}$ regionie. $\mathrm{W}$ analizowanym okresie powierzchnia uprawy rzepaku i rzepiku uległa prawie pięciokrotnemu zwiększeniu [Raport 2011]. 


\section{Kierunki rozwoju rolnictwa w województwie podlaskim}

Przeprowadzone analizy wskazują, że po akcesji Polski do Unii Europejskiej zaszły widoczne zmiany zarówno w rolnictwie województwa podlaskiego, jak i w kraju. Kierunki tych zmian są bardzo podobne. Wpływ na taki stan rzeczy miało wsparcie kierowane do tego sektora gospodarki narodowej. Aby jednak mogło ono przynosić oczekiwane skutki, niezbędne jest jego kierowanie zgodnie z rzeczywistymi potrzebami. Województwo podlaskie, pomimo niekorzystnych warunków agroklimatycznych do prowadzenia działalności rolniczej, ma także wiele atutów. Upatrywać ich należy przede wszystkim w znacznej jego naturalności. Na jego obszarze duże szanse powodzenia i perspektywy rozwoju ma wzrost znaczenia produkcyjnej funkcji rolnictwa, realizowanej zarówno w nowo tworzonych lub powiększonych, na bazie już istniejących, dużych wysokotowarowych gospodarstwach rolnych. W województwie podlaskim funkcjonuje duża grupa gospodarstw towarowych specjalizujących się w produkcji bydła mlecznego, która obecnie, i zapewne w przyszłości, będzie wiodącym kierunkiem produkcji rolnej w tym regionie. Dzięki możliwości korzystania z unijnego wsparcia finansowego, do którego dostęp wiąże się ze spełnieniem wielu kryteriów przez gospodarstwo ubiegające się o wsparcie, zyskuje na jakości nie tylko wytworzona żywność, ale i środowisko, ponieważ gospodarstwa zobligowane są również do świadczenia usług dla środowiska: zachowanie bioróżnorodności, poprawa dobrostanu zwierząt.

Wydaje się, że wprowadzanie do rolnictwa podlaskiego gospodarki opartej na zasadach ekologicznych (rolnictwo ekologiczne) w połączeniu z alternatywnymi sposobami gospodarowania może być dla niego szansą na rozwój i wzrost konkurencyjności. Możliwości rozwojowe dla takiej produkcji stwarza podejmowanie przez rolników działań w zakresie programów rolno-środowiskowych w ramach Programu Rozwoju Obszarów Wiejskich [Kozłowska-Burdziak 2012]. Za rolniczą produkcją ekologiczną, jako ważnym składnikiem rozwoju tego regionu, przemawiają jego uwarunkowania (głównie dość ekstensywne systemy rolnicze aktualnie stosowane i dobry stan środowiska naturalnego). Ponadto jest to zgodne z kształtowaniem się modelu rolnictwa europejskiego, w którym nacisk kładzie się na wielofunkcyjny rozwój rolnictwa i obszarów wiejskich, realizującego funkcje: produkcyjna, społeczną, ekonomiczna, ekologiczną i kulturową [Faber i Kuś 2003, Vandermeulen i in. 2006]. Prowadzenie gospodarki rolnej na ekologicznych zasadach w połączeniu $\mathrm{z}$ alternatywnymi sposobami gospodarowania staje się jednym z czynników rozwoju obszarów wiejskich województwa podlaskiego. 


\section{2}

Jednym z coraz wyraźniej zarysowujących się alternatywnych kierunków produkcji rolnictwa polskiego jest produkcja biomasy na cele energetyczne. W województwie podlaskim część gruntów marginalnych może stanowić doskonałą bazę do wykorzystania na cele niekonwencjonalnego zagospodarowania rolniczego (np. rośliny energetyczne, uprawa roślin leczniczych i przyprawowych) lub zagospodarowania najsłabszych gleb na cele pozarolnicze (głównie leśnictwo). Wielofunkcyjne wykorzystanie ziem marginalnych przyczyni się do wyrównywania na nich niedoborów renty gruntowej w stosunku do obszarów o sprzyjających uwarunkowaniach do prowadzenia intensywnej produkcji i tym samym stworzy warunki do trwałego i zrównoważonego rozwoju tych obszarów [Roszkowska-Mądra 2010, s. 284].

Wzrost zainteresowania działalnością pozarolniczą w gospodarstwach rolnych województwa podlaskiego jest zauważalny. Potwierdzeniem tego jest większy udział gospodarstw rolnych decydujących się na prowadzenie działalności pozarolniczej. W związku z tym wydaje się, że ze względu na niewielkie dochody z działalności rolniczej znacznej grupy gospodarstw w województwie, pożądane będzie w dalszym ciągu wzbogacanie (dywersyfikacja) tradycyjnej działalności rolniczej o różne formy przedsiębiorczości, aby zapewnić ludności rolniczej trwałe warunki rozwoju. W tej kwestii wielka rola powinna być przypisana władzy lokalnej, która dzięki organizowaniu szkoleń zachęcałaby do uruchamiania przedsięwzięć pozarolniczych na wsi, przyczyniając się w ten sposób do poprawy życia jej mieszkańców. Poprawa jakości życia na obszarach wiejskich i różnicowanie gospodarki wiejskiej realizowano w ramach Wspólnej Polityki Rolnej, zarówno w latach 2004-2006, jak i w kolejnym okresie budżetowania UE - w latach 2007-2013 w ramach osi 3 PROW przez dwie grupy instrumentów. Pierwsza grupa miała za cel różnicowanie działalności gospodarczej i realizowana była przez dwa działania (Różnicowanie w kierunku działalności nierolniczej i Tworzenie i rozwój mikroprzedsiębiorstw). Dawała ona ogromną szansę dla obszarów wiejskich, przede wszystkim przez możliwość tworzenia dodatkowych źródeł dochodów dla ludności zdecydowanej kontynuować rodzinną tradycję prowadzenia gospodarstw rolnych po swych przodkach. Druga grupa instrumentów, której celem była poprawa jakości życia, dotyczyła odnowy wsi oraz poprawy stanu dziedzictwa kulturowego i przyrodniczego. Stanowiła ona ważny czynnik przeciwdziałający depopulacji i wspomagający tworzenie silniejszego poczucia identyfikacji mieszkańców obszarów wiejskich z ich regionem wraz z jego tradycjami i wartościami [Roszkowska-Mądra 2010]. 


\section{Wnioski}

Z przeprowadzonych badań wynika, że rolnictwo w województwie podlaskim odgrywa ważną rolę. Po akcesji Polski do Unii Europejskiej zaszły widoczne zmiany $\mathrm{w}$ rolnictwie województwa podlaskiego. Kierunki tych zmian są podobne do tych, które uwidoczniły się w całym polskim rolnictwie. W województwie podlaskim przejawiają się one we wzroście średniej powierzchni gospodarstw rolnych, wzroście skali produkcji zwierzęcej oraz w zauważalnym wzroście zainteresowania działalnością pozarolniczą gospodarstw rolnych. Wpływ na to miał transfer środków z Unii Europejskiej na rozwój rolnictwa. Umożliwił on bardziej zdywersyfikowane, wielofunkcyjne i zrównoważone prowadzenie działalności rolniczej. Odnotowano wzrost zainteresowania prowadzeniem zarówno ekologicznej, jak i bardziej intensywnej produkcji żywności o wysokiej jakości oraz rozwijanie przedsiębiorczości pozarolniczej we własnym gospodarstwie rolnym i poza nim. Umożliwiło to wzrost dochodów i jakości życia ludności rolniczej.

Kierunki zmian w rolnictwie województwa podlaskiego po integracji z UE należy uznać za pozytywne oraz umożliwiające realizację idei zrównoważonego i wielofunkcyjnego rozwoju rolnictwa. Idea ta jest propagowana przez politykę Unii Europejskiej i powszechnie akceptowana przez społeczność europejską.

\section{Literatura}

Analiza kierunków rozwoju i aktualna sytuacja w rolnictwie województwa podlaskiego, 2011: Podlaski Ośrodek Doradztwa Rolniczego w Szepietowie, Szepietowo.

Analiza kluczowych sektorów województwa podlaskiego - sektor rolnictwa, 2012: WUP, Białystok.

Charakterystyka gospodarstw rolnych, Powszechny Spis Rolny 2010, GUS, Warszawa 2012.

FABER A., KUŚ J., 2003: Alternatywne kierunki produkcji rolnictwa polskiego, „Pamiętnik Puławski”, z. 132, 59-71.

http://www.arimr.gov.pl/pomoc-unijna/wdrazane-programy-i-dzialania-dane-liczbowe/program-rozwojuobszarow-wiejskich-2007-2013/roznicowanie-w-kierunku-dzialalnoscinierolniczej.html (data dostępu: 7.10.2014).

KOZLOWSKA-BURDZIAK M., 2012: Rola programów unijnych w rozwoju przedsiębiorczości w rolnictwie i na obszarach wiejskich w Polsce, ,Optimum-Studia Ekonomiczne", $\operatorname{nr} 2$ (56), 93-112.

KULIKOWSKI R., 2003: Obszary problemowe rolnictwa w Polsce, [w:] A. Ciołkosz (red.), Charakterystyka rolniczej przestrzeni produkcyjnej Polski, PSR, GUS, Warszawa, 179-185.

Ludność i gospodarstwa domowe zwiazane z rolnictwem. Województwo podlaskie, PSR 2002, 2003, US, Białystok 2003. 


\title{
114
}

Raport z wyników województwa podlaskiego, Powszechny Spis Rolny 2010, WUS, Białystok 2011.

Rocznik Branżowy Rolnictwo 2011, GUS, Warszawa 2011.

Rocznik Statystyczny Województw, GUS, Warszawa 2011.

ROSZKOWSKA-MĄDRA B., 2010: Obszary wiejskie o niekorzystnych warunkach gospodarowania w aspekcie ich zrównoważonego rozwoju, Wydawnictwo Uniwersytetu w Białymstoku, Białystok.

Środki produkcji w rolnictwie w roku gospodarczym 2010/2011, GUS, Warszawa 2011.

WILKIN J., 2010: Wielofunkcyjność rolnictwa - nowe ujęcie roli rolnictwa $w$ gospodarce i społeczeństwie, [w:] J. Wilkin (red.), Wielofunkcyjność rolnictwa. Kierunki badań, podstawy metodologiczne i implementacje praktyczne, IRWiR PAN, Warszawa.

VANDERMEULEN V., VERSPECHT A., VAN HUYLENBROECK G., MEERT H., BOULANGER A., VAN HECKE E., 2006: The Importance of the Institutional Environment on Multifunctional Farming Systems in the Peri-urban Area of Brussels, Land Use Policy 23, 486-501.

\section{Changes in agriculture of Podlaskie region after accession to the European Union}

\begin{abstract}
The objective of this paper was to assess major changes within agricultural economic activities in Podlaskie region (NUTS 2) which occurred between 2002 and 2012. These economic changes in family farms (a dominant form of farming in Podlaskie) across the region were found to be substantial as a result of implementation of the funds offered by the European Union (EU) within Common Agricultural Policy (CAP). Over this period the number of farms in the region decreased by 13\%, average Utilized Agricultural Area (UAA) of commercial farms increased up to 11.38 ha, and livestock production increased substantially. Additionally, structure and intensity of non-agricultural activities in farm households both on- and off-farm improved. Livestock production predominated (approaching to $90 \%$ ) within commercial agricultural production; dairy production was approximately $50 \%$ of total livestock production. It was proved that the EU funds implemented to Polish agriculture over 10 years, since 2004 until 2012, caused more diversification and multi-functionality and, through this, more sustainable economic activity in family farms across Podlaskie region.
\end{abstract}

